\title{
PLANTS FROM JEPI MOUNTAINS, BUCEGI, PRESENT IN "ALEXANDRU BELDIE" HERBARIUM
}

\author{
Crisan Vlad ${ }^{1}$, Lucian Dincă ${ }^{1}$, Sorin Deca ${ }^{2 *}$ \\ 1 “Marin Drăcea” National Institute for Research and Development in Forestry, Romania \\ ${ }^{2} \mathrm{PhD}$ student at the Romanian Academy of Advanced Studies - Bucharest, Romania
}

\section{Current Trends in}

\section{Natural Sciences}

\begin{abstract}
The present article describes the plants collected from Jepi Mountains area (Bucegi) and present in one of the most important Romanian herbarium - "Alexandru Beldie" Herbarium from "Marin Drăcea" National Institute for Research and Development in Forestry. The article presents the studied material, the number of vouchers with species harvested from this area as well as some characteristics of this great plant collection. The most important species collected from Jepi Mountains are also mentioned, with an analysis of their characteristics: the collection's creation period and the plant's harvesting periods. The plants collected from this area belong to 54 different genera. Most of them belong to Hieracium and Gentiana and were collected during the last century, starting with 1900 and ending in 1999. The found genera were systematized, with an emphasis on the most representative ones. Furthermore, the specialists that had an important contribution for the representation of Jepi Mountains within the herbarium are also mentioned and honored.
\end{abstract}

Keywords: “Alexandru Beldie” Herbarium, Jepi Mountains, plant vouchers.

\section{INTRODUCTION}

Bucegi Mountains belong to the Southern Carpathians and are located in their East part. Prahova Valley separates them from the Curvature Carpathians (figure 1). The highest peak is represented by Omu Peak, with an altitude of $2505 \mathrm{~m}$. The highest area of the Bucegi Mountains is a large complex of structural plateaus located at an altitude between 1800 and $2500 \mathrm{~m}$, and a local relief index of no more than 400-500 m, usually 100-200 m (Mihai et al., 2009).

"Alexandru Beldie" Herbarium was created in 1929 and is inscribed in Index Herbariorum, having the international BUCF code. With approximately 40.000 vouchers (Vechiu et al., 2018a; Dincă et al., 2018), the herbarium is owned by „Marin Drăcea” National Institute for Research and Development in Forestry from Bucharest.

The herbarium contains numerous vouchers initially harvested by Al. Beldie himself and then enriched by exchanges with other national or international herbariums. As such, the herbarium is nowadays one of the most important from our country. Among the genera of plants present in this herbarium we mention: 36 Bromus species (Tudor et al., 2019), 21 Agrostis species (Cântar et al., 2019), 33 Orobanche species (Scărlătescu et al., 2017a), 42 Alnus species (Dincă et al., 2019), 6 Vaccinium species (Scărlătescu et al., 2017b), 80 Trifolium species (Cântar et al., 2018), 19 Centaurea species (Dincă et al., 2017) and 7 Lycopodium species (Vechiu et al., 2018b). 


\begin{tabular}{|c|c|}
\hline & $\begin{array}{c}\text { Current Trends in Natural Sciences } \\
\text { Vol. 9, Issue 17, pp. 160-167, 2020 } \\
\text { https://doi.org/10.47068/ctns.2020.v9i17.019 }\end{array}$ \\
\hline $\begin{array}{l}\text { Current Trends in Natural Sciences (on-line) } \\
\text { ISSN: 2284-953X } \\
\text { ISSN-L: 2284-9521 }\end{array}$ & $\begin{array}{l}\text { Current Trends in Natural Sciences (CD-Rom) } \\
\text { ISSN: 2284-9521 } \\
\text { ISSN-L: 2284-9521 }\end{array}$ \\
\hline
\end{tabular}

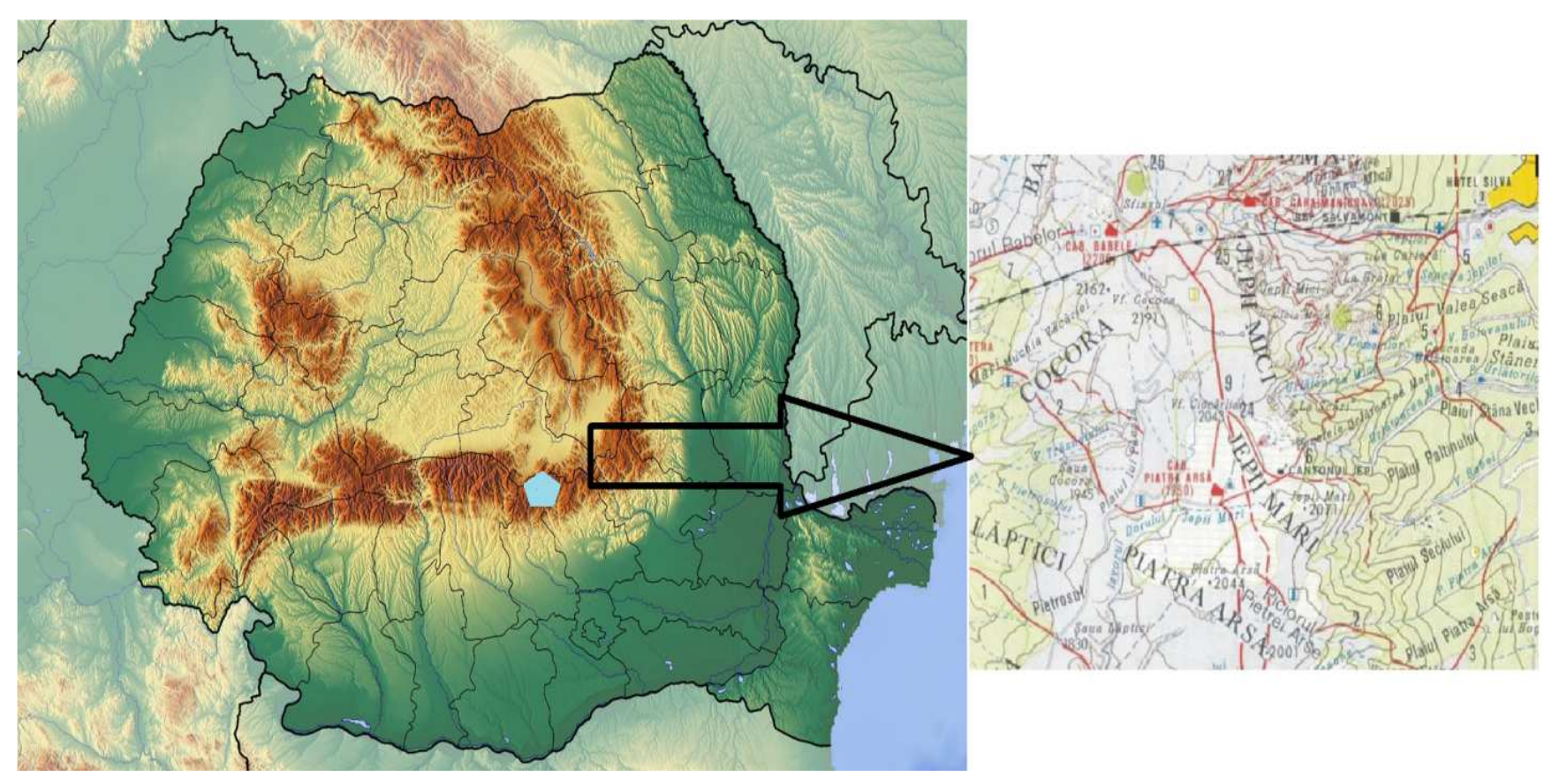

Figure 1. The map of harvesting places for the plants from Jepi Mountains area (Bucegi)

\section{MATERIALS AND METHODS}

The material that was used for the present article is composed of 146 vouchers belonging to different genera from the studied area. The database was created with the information inscribed on the identification labels of each voucher. As such, the following data was taken from the labels: drawer number, voucher number, plant's scientific name, collection name, harvesting date, harvesting place, the name of the person who has collected or identified the plant. Due to the fact that the creation of the database has involved the analysis of each voucher, another characteristic was also added, namely the conservation degree of each specimen. In this way, a grade from 1 to 4 was given to each specimen as follows: 1 for an entire plant, correctly attached to the voucher and well conserved; 2 for the plant detached from the voucher with existent but detached parts; 3 for plant detached from the voucher with missing parts and 4 for plant detached and fragmented, with over $50 \%$ of its parts missing. The next step was to verify if their scientific name is accepted at an international level followed by their update based on The Plant List (www.iucnredlist.org; www.theplantlist.org; www.ipni.org; ww2.bgbm.org/EuroPlusMed/query.asp).

\section{RESULTS AND DISCUSSIONS}

After the vouchers were analysed and systematized, 146 vouchers were identified as containing plants collected from Bucegi Mountains, namely from Jepi Mountains. The vouchers belong to more than 54 genera, with the most representative plants from this area belonging to: Hieracium (18 samples from 11 species), Gentiana (16 samples belonging to 6 species), Trifolium (8 samples from 3 species), Bupleurum (7 samples from 3 species).

An excerpt concerning the vouchers that contain plants collected from Bucegi Mountains, area of Jepi Mountains is rendered in table no.1. 


\section{Current Trends in Natural Sciences}

Vol. 9, Issue 17, pp. 160-167, 2020

https://doi.org/10.47068/ctns.2020.v9i17.019

Current Trends in Natural Sciences (on-line)

ISSN: 2284-953X

Current Trends in Natural Sciences (CD-Rom)

ISSN: 2284-9521

ISSN-L: 2284-9521

ISSN-L: 2284-9521

Table 1. Plants harvested from Jepi Mountains area (Bucegi Mountains) and present in "Alexandru Beldie" Herbarium from "Marin Drăcea” National Institute for Research and Development in Forestry - excerpt

\begin{tabular}{|c|c|c|c|c|c|c|c|}
\hline $\begin{array}{l}\text { Drawer } \\
\text { number }\end{array}$ & $\begin{array}{l}\text { Voucher } \\
\text { number }\end{array}$ & $\begin{array}{c}\text { Herbarium/ Botanic } \\
\text { Collection / Institution } \\
\text { (from the voucher's } \\
\text { label) }\end{array}$ & $\begin{array}{c}\text { Species } \\
\text { (from the voucher's } \\
\text { label) }\end{array}$ & $\begin{array}{l}\text { Harvesting } \\
\text { Date } \\
\text { (from the } \\
\text { voucher's } \\
\text { label) }\end{array}$ & $\begin{array}{l}\text { Harvesting Place } \\
\quad \text { (from the } \\
\text { voucher's label) }\end{array}$ & $\begin{array}{c}\text { Collected/ } \\
\text { Determined } \\
\text { by }\end{array}$ & $\begin{array}{c}\text { Conser } \\
\text { vation } \\
\text { Degree } \\
(1 \ldots 4)\end{array}$ \\
\hline 60 & 79 & $\begin{array}{c}\text { Al. Beldie Herbarium } \\
\text { Bucharest }\end{array}$ & $\begin{array}{c}\text { Bromus barcensis } \mathrm{Si} \\
\text { mk. var. romanicus }\end{array}$ & 1937.09.01. & $\begin{array}{l}\text { Bucegi, Jepi } \\
\text { Valley }\end{array}$ & Al. Beldie & 1 \\
\hline 60 & 86 & $\begin{array}{c}\text { Bucharest } \\
\text { Polytechnics School } \\
\text { Herbarium, Botanic } \\
\text { Laboratory }\end{array}$ & $\begin{array}{l}\text { Bromus barcensis } \mathrm{Si} \\
\text { mk. var. romanicus }\end{array}$ & 1940.09.01. & $\begin{array}{l}\text { Bucegi, Jepi } \\
\text { Valley }\end{array}$ & Al. Beldie & 1 \\
\hline 155 & 46 & $\begin{array}{l}\text { The Institute of } \\
\text { Forestry Research } \\
\text { and Experimentations }\end{array}$ & $\begin{array}{l}\text { Galium erectum } \\
\text { Huds. }\end{array}$ & 1993.08.03. & $\begin{array}{l}\text { Bucegi, Jepi } \\
\quad \text { Valley }\end{array}$ & Al. Beldie & 1 \\
\hline 156 & 14 & $\begin{array}{c}\text { Al. Beldie Herbarium } \\
\text { Bucharest }\end{array}$ & $\begin{array}{c}\text { Galium schultesii } \\
\text { Vest. }\end{array}$ & 1935.05.01. & $\begin{array}{c}\text { Bucegi, Jepi } \\
\text { Valley } 1150 \mathrm{~m}\end{array}$ & Al. Beldie & 1 \\
\hline 87 & 6 & $\begin{array}{c}\text { Al. Beldie Herbarium } \\
\text { Bucharest }\end{array}$ & $\begin{array}{l}\text { Gentiana phlogifolia } \\
\text { Schott et Kotschy }\end{array}$ & 1935.08.01. & $\begin{array}{c}\text { Bucegi, Jepii } \\
\text { Mici Mountains }\end{array}$ & Al. Beldie & 3 \\
\hline 122 & 76 & $\begin{array}{c}\text { Bucharest } \\
\text { Polytechnics School } \\
\text { Herbarium, } \\
\text { Silviculture Faculty }\end{array}$ & $\begin{array}{l}\text { Dianthus tenuifolius } \\
\text { Schur. }\end{array}$ & 1948.09.02. & $\begin{array}{l}\text { Bucegi, Seaca } \\
\text { Valley of Jepi } \\
\text { Mountains }\end{array}$ & Al. Beldie & 1 \\
\hline 44 & 70 & $\begin{array}{c}\text { Bucharest } \\
\text { Polytechnics School } \\
\text { Herbarium, Botanic } \\
\text { Laboratory } \\
\end{array}$ & $\begin{array}{c}\text { Artemisia petrosa } \mathrm{Ba} \\
\text { um. ssp. carpatica }\end{array}$ & 1939.09.03. & $\begin{array}{l}\text { Bucegi, Jepi } \\
\text { Valley }\end{array}$ & P. Cretzoiu & 2 \\
\hline 47 & 21 & $\begin{array}{c}\text { Bucharest } \\
\text { Polytechnics School } \\
\text { Herbarium }\end{array}$ & $\begin{array}{l}\text { Trifolium repens } \\
\text { L.var. ochranthum }\end{array}$ & 1940.09.01 & $\begin{array}{l}\text { Bucegi, Jepi } \\
\text { Valley }\end{array}$ & $\begin{array}{l}\text { P. Cretzoiu, } \\
\text { Al. Beldie }\end{array}$ & 1 \\
\hline 62 & 49 & $\begin{array}{c}\text { Bucharest } \\
\text { Polytechnics School } \\
\text { Herbarium, Botanic } \\
\text { Laboratory } \\
\end{array}$ & $\begin{array}{c}\text { Bupleurum falcatum } \\
\text { L. }\end{array}$ & 1946.08.01 & $\begin{array}{l}\text { Bucegi, Jepi } \\
\text { Mountains }\end{array}$ & Al .Beldie & 2 \\
\hline 37 & 1 & $\begin{array}{l}\text { The Institute of } \\
\text { Forestry Research } \\
\text { and Experimentations }\end{array}$ & $\begin{array}{l}\text { Hieracium } \\
\text { nigrescens }\end{array}$ & 1935.03.09 & $\begin{array}{l}\text { Bucegi, Jepii } \\
\text { Mici Mountains }\end{array}$ & Al. Beldie & 1 \\
\hline
\end{tabular}

In the area of Jepi Mountains there were also identified following species in "Alexandru Beldie" Herbarium: Achillea millefolium subsp. stricta (Schleich. ex Heimerl) Hyl., Aconitum anthora L., Aconitum toxicum Rchb., Elymus caninus (L.) L., Agrostis rupestris All., Alchemilla glaucescens Wallr., Alchemilla heteropoda Buser, Alchemilla obtusa Buser, Alchemilla fissa Günther \& Schummel., Allium oleraceum L., Androsace lactea L., Anemone narcissiflora L., Angelica archangelica L., Cota tinctoria subsp. fussii (Griseb. \& Schenk) Oberpr. \& Greuter, Anthyllis alpestris (Schult.) Kit., Angelica archangelica L., Arenaria biflora L., Artemisia umbelliformis subsp. eriantha (Ten.) Vallès-Xirau \& Oliva Brañas, Astrantia major L., Helictotrichon pubescens (Huds.) Schult. \& Schult.f., Helictotrichon planiculme (Schrad.) Pilg., Brachypodium pinnatum (L.) P.Beauv., Bromus riparius Rehmann, Bupleurum falcatum subsp. cernuum (Ten.) Arcang., Bupleurum falcatum L., Bupleurum longifolium L., Conioselinum vaginatum (Spreng.) Thell., Dianthus carthusianorum subsp. tenuifolius (Schur) Hegi, Kobresia myosuroides (Vill.) Fiori, Equisetum hyemale L., Equisetum pratense Ehrh., Festuca amethystina L., Festuca altissima All., Galium austriacum Jacq., Galium album Mill., Galium mollugo L., Galium intermedium Schult., Galium verum L., Gentiana asclepiadea L., Gentiana acaulis L., Gentiana cruciata L., Gentianella 
lutescens (Velen.) Holub, Gentianella austriaca (A.Kern. \& Jos.Kern.) Holub, Gentiana punctata L., Gentiana verna L., Hedysarum hedysaroides (L.) Schinz \& Thell., Hieracium bifidum Ser. ex Froel., Hieracium fritzei F.W.Schultz, Hieracium murorum C.B.Clarke, Hieracium murorum subsp. medianum (Griseb.) Zahn, Hieracium nigrescens Willd., Hieracium pietroszense Degen \& Zahn, Hieracium praecurrens Vuk., Hieracium prenanthoides subsp. lanceolatum (Vill.) Zahn, Pilosella stoloniflora (Waldst. \& Kit.) F.W.Schultz \& Sch.Bip., Hieracium villosum Jacq., Hieracium villosum subsp. ovalifolium Nägeli \& Peter, Hypochoeris argentina Cabrera, Minuartia recurva (All.) Schinz \& Thell., Ornithogalum gussonei Ten., Orobanche alba Stephan ex Willd., Orobanche caryophyllacea Sm., Phyteuma spicatum L., Pinus mugo Turra, Plantago montana Huds., Persicaria bistorta (L.) Samp., Primula elatior (L.) Hill, Primula veris L., Ranunculus montanus Willd., Ranunculus oreophilus M.Bieb., Ranunculus serpens subsp. nemorosus (DC.) G.López, Rubus saxatilis L., Podospermum roseum (Waldst. \& Kit.) Gemeinholzer \& Greuter, Tephroseris integrifolia subsp. capitata (Wahlenb.) B.Nord., Senecio integerrimus var. major (A.Gray) Cronquist, Senecio supernitens, Sesleria coerulans Friv., Sesleria coerulans Friv., Silene nutans L., Solidago virga-aurea L., Sorbus aucuparia L., Telekia speciosa (Schreb.) Baumg., Thesium alpinum L., Thymus pulegioides subsp. montanus (Benth.) Ronniger, Trifolium alpestre L., Trifolium pratense L., Trifolium repens L., Trifolium repens var. ochranthum K.Maly, Trifolium repens var. orphanideum (Boiss.) Boiss., Vaccinium uliginosum L..

Hieracium belongs to the Asteraceae family and is a perennial herb. They are complex plants with an intricate pattern of morphological variation and reproductive systems (Zeljko et al., 2008). According to the International Plant Names Index, there are more than 12.000 names for this species including subspecies and synonymous. The majority of Hieracium species can be found in the Alps and Central Europe, but they also occur in North America and Asia. It grows in forests and forest margins, pastures, screes, rocks and disturbed ground. In the area of Jepi Mountains botanists found following Hieracium species: Hieracium bifidum Ser. ex Froel., Hieracium fritzei F.W.Schultz, Hieracium murorum C.B.Clarke, Hieracium murorum subsp. medianum (Griseb.) Zahn, Hieracium nigrescens Willd., Hieracium pietroszense Degen \& Zahn, Hieracium praecurrens Vuk., Hieracium prenanthoides subsp. lanceolatum (Vill.) Zahn, Pilosella stoloniflora (Waldst. \& Kit.) F.W.Schultz \& Sch.Bip., Hieracium villosum Jacq., Hieracium villosum subsp. ovalifolium Nägeli \& Peter.

Gentiana genus is part of the Gentianales order, Gentianaceae family. This genus includes approximately 400 species which are found mainly in the alpine areas of the temperate regions of Asia, Europe and America. It prefers neutral and acidic soils rich in humus and well-drained. "Alexandru Beldie" Herbarium contains more than 60.000 plates from which 206 belong to the Gentiana genus (Enescu et al., 2018). The Gentiana species found in Jepi mountains are the following: Gentiana asclepiadea L., Gentiana acaulis L., Gentiana cruciata L., Gentianella lutescens (Velen.) Holub, Gentianella austriaca (A.Kern. \& Jos.Kern.) Holub, Gentiana punctata L., and Gentiana verna L.. The most numerous Gentiana species found in "Alexandru Beldie" Herbarium harvested all over Romania are the following: Gentiana asclepiadea L. (21 plates), Gentianopsis ciliata L. (10 plates), Gentiana Gentiana acaulis L. (11 plates), Gentianella lutescens (Velen.) Holub (25 plates), Gentiana verna L. (23 plates) and Gentiana utriculosa L. (20 plates) (Enescu et al., 2018).

Trifolium genus is very large and includes annual and perennial species. Numerous Trifolium species were originally native to the middle and south of Europe, North Africa and the area ranging from Asia Minor to China. Trifolium species are found in a wide variety of moist habitats 


\section{Current Trends in Natural Sciences}

Vol. 9, Issue 17, pp. 160-167, 2020

https://doi.org/10.47068/ctns.2020.v9i17.019

Current Trends in Natural Sciences (on-line)

ISSN: 2284-953X

Current Trends in Natural Sciences (CD-Rom)

ISSN: 2284-9521

ISSN-L: 2284-9521

ISSN-L: 2284-9521

throughout those areas (Sabudak and Guler, 2009). Botanists have found three species belonging to this genus in Jepi Valley from Bucegi Mountains: Trifolium alpestre L., Trifolium pratense L. and Trifolium repens $\mathrm{L}$.

The plants collected from Jepi Mountains (Bucegi) that are present in "Alexandru Beldie" Herbarium are in a good conservation state.

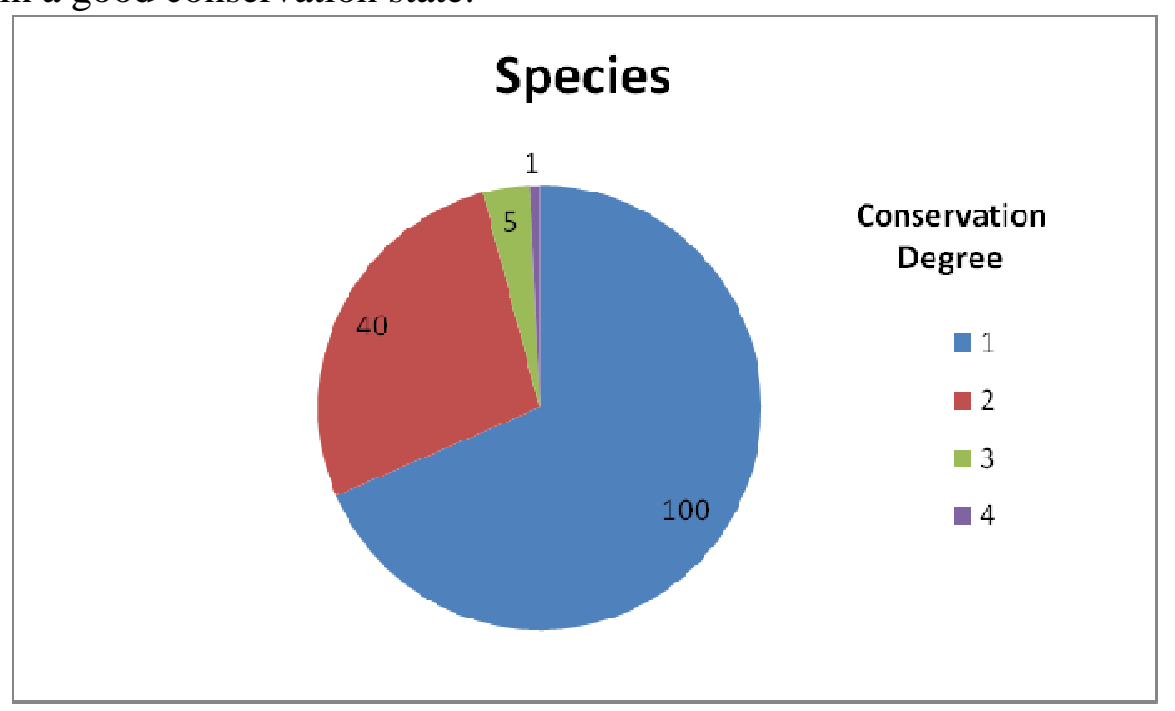

Figure 2. Conservation degree of species collected from Jepi Mountains

As such, from the total of 146, the majority of vouchers, namely 100, are in a very good conservation state. 40 vouchers are in a good conservation state, while 5 vouchers are in a weak conservation state and only one is in a very poor state (figure 2 ). The majority of vouchers are kept in their original maps (figures 3,4).
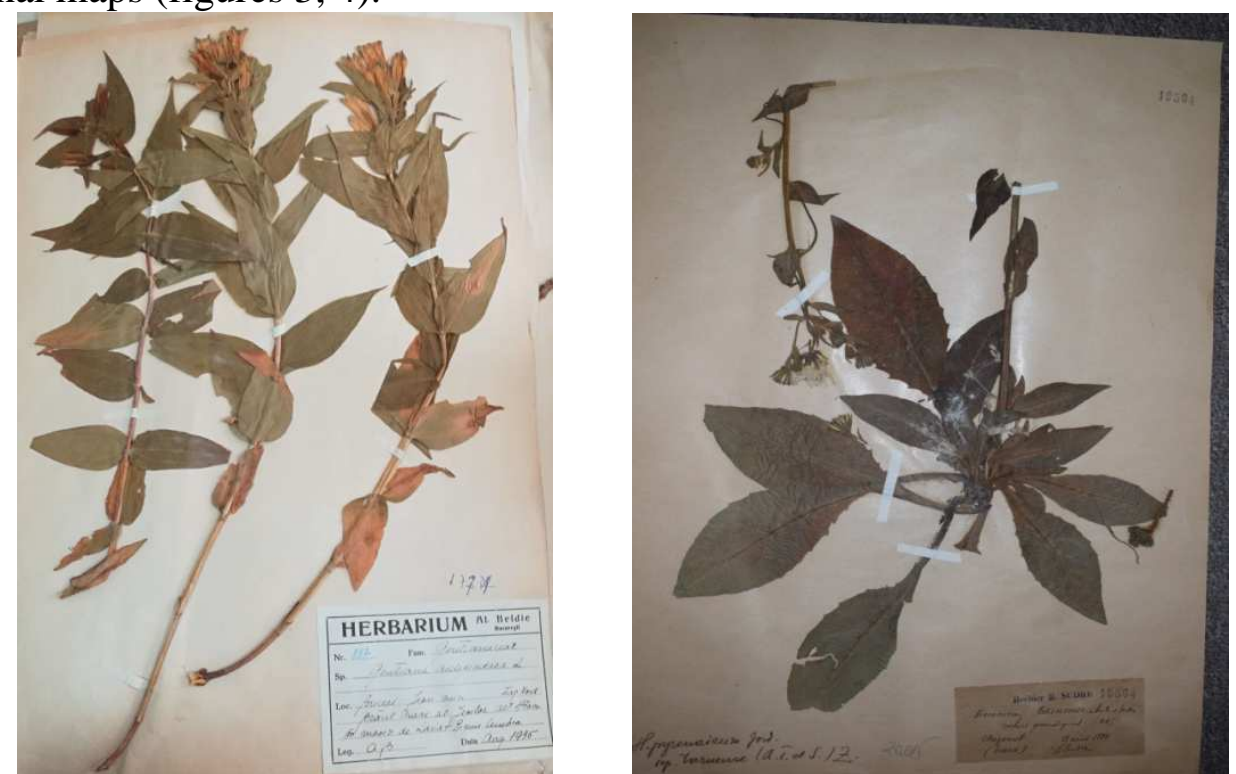

Figure 3. Vouchers with plants from Jepi Mountains (Bucegi) present in "Alexandru Beldie" Herbarium, "Marin Drăcea” National Institute for Research and Development in Forestry (Gentiana asclepiadea L. - left, Hieracium carneum Greene - right) 


Current Trends in Natural Sciences
Vol. 9, Issue 17, pp. 160-167, 2020
https://doi.org/10.47068/ctns.2020.v9i17.019
Current Trends in Natural Sciences (CD-Rom)
ISSN: 2284-9521
ISSN-L: 2284-9521

ISSN: 2284-953X

ISSN-L: 2284-9521
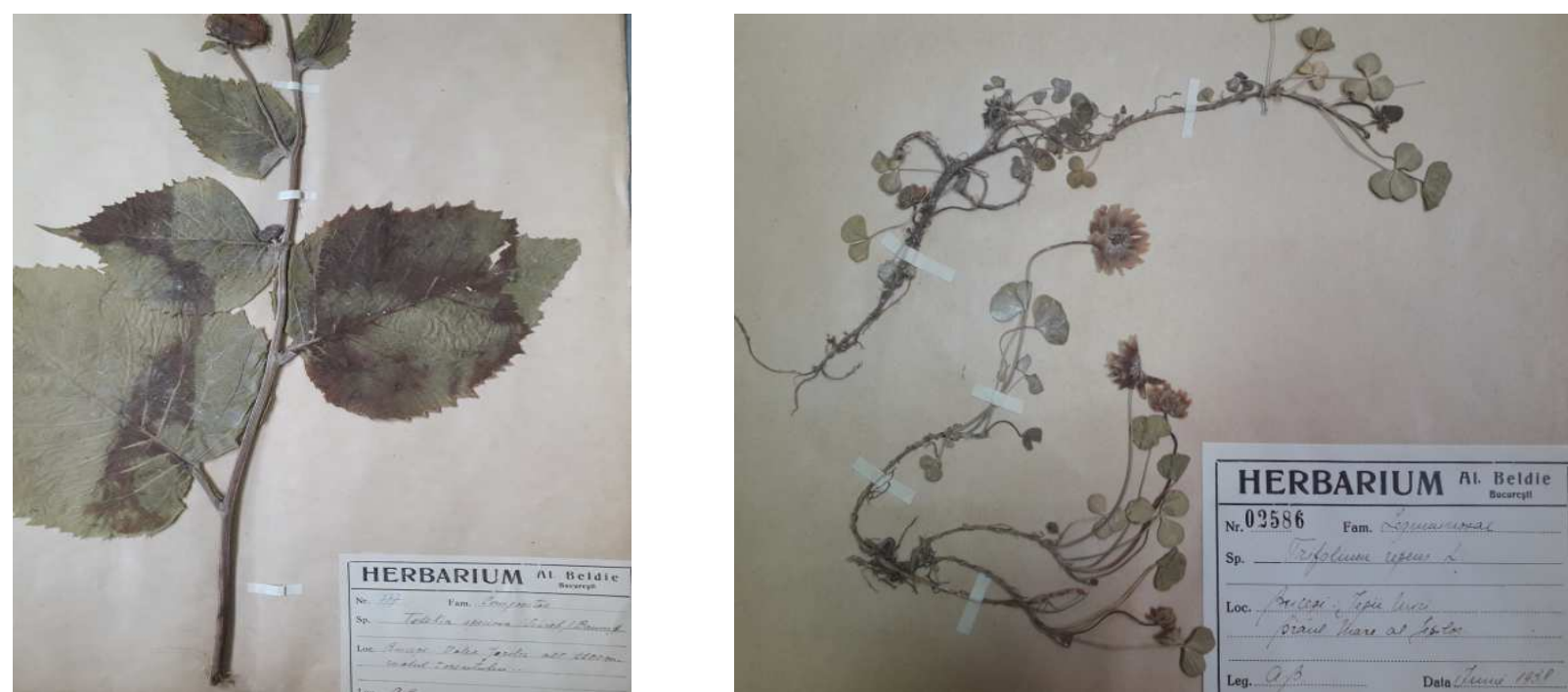

Figure 4. Vouchers with plants from Jepi Mountains (Bucegi) present in "Alexandru Beldie" Herbarium, "Marin Drăcea” National Institute for Research and Development in Forestry (Telekia speciosa - left, Trifolium repens right)

The plants gathered from Jepi Mountains (Bucegi) and present in "Alexandru Beldie" Herbarium were systematized based on their harvesting year. This has allowed for an observation of the periods in which the plants were gathered and when this area of Bucegi Mountains were an important area for the herbarium's development. These periods can also be analysed in figure 5 .

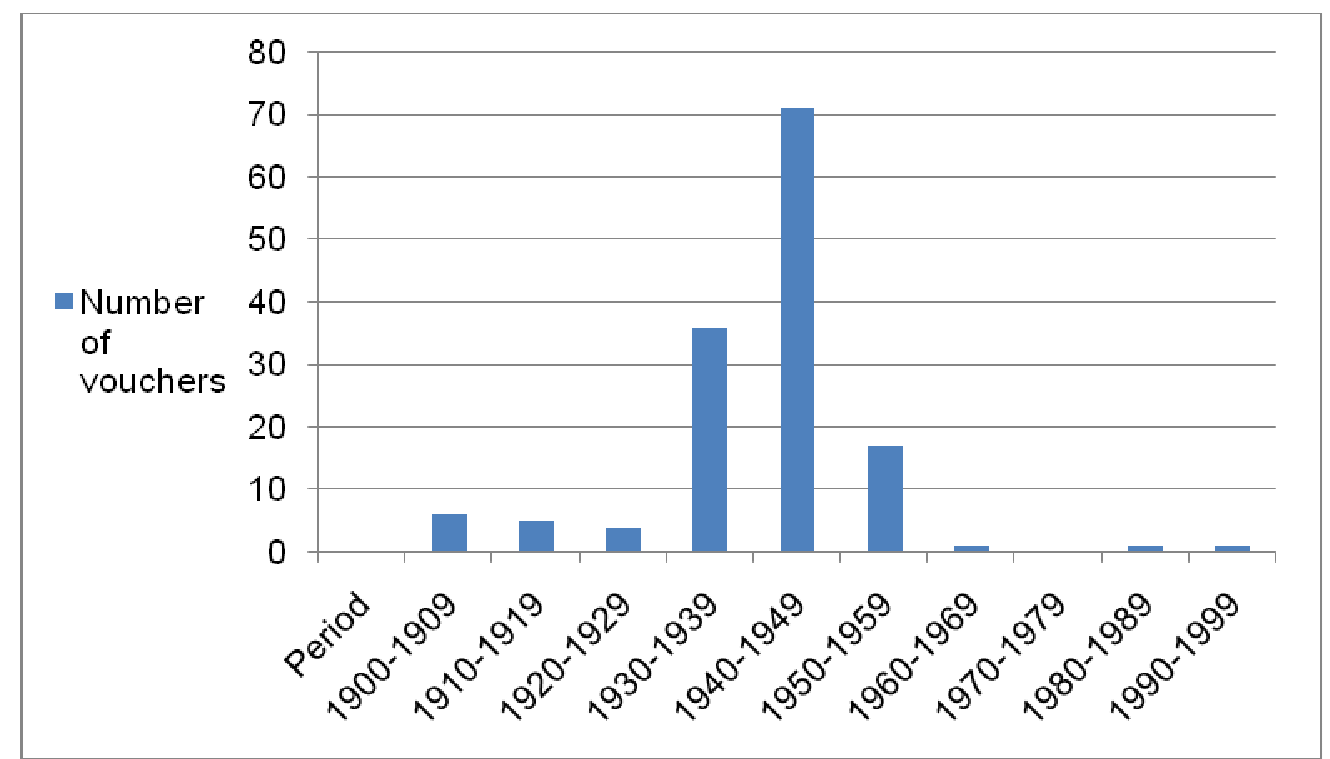

Figure 5. Harvesting periods for plants from Bucegi Mountains that can be found in "Alexandru Beldie" Herbarium

As such, from a total of 146 plants, the majority (71) were collected during 1940-1949 (figure 5).

The majority of plants harvested from this area amount to 114 and were gathered by Alexandru Beldie himself who was very attached to this area. As such, Alexandru Beldie has known in detail the flora and vegetation from Bucegi Mountains and is considered the father of Bucegi Natural 
Reservation, being also its first custodian (Vasile et al., 2016). In addition, "Alexandru Beldie" Herbarium also contains vouchers with plants collected by other botanists from this region such as C.C. Georgescu (whose name is present on 2 vouchers), M. Haret (14 vouchers), M. Brandza (2 vouchers), P. Cretzoiu (6 vouchers), R. Zitti, T. Bunea and I. Todor (each with one voucher).

\section{CONCLUSIONS}

Jepi Mountains area (Bucegi) represents a territory with a rich biodiversity and has represented in the past as well as in the present, an important source for the development and enrichment of "Alexandru Beldie" Herbarium from "Marin Drăcea" National Institute for Research and Development in Forestry.

The plants collected from this area belong to 54 different genera. Most of them belong to Hieracium and Gentiana and were collected during the last century, starting with 1900 and ending in 1999.

Numerous plant species from Jepi Mountains (Bucegi) can be found in "Alexandru Beldie" Herbarium.

Even though more than 100 vouchers were collected by the famous botanist Alexandru Beldie, approximately 9 specialists have covered the forests, meadows and pastures from Jepi Mountains (Bucegi) in order to collect plants that have extended the collections from this herbarium.

\section{REFERENCES}

Cântar, I.C., Dincă, L. (2018). Trifolium genus species present in "Alexandru Beldie" Herbarium from "Marin Drăcea" National Institute for Research and Development in Forestry. Annals of West University of Timisora, ser. Biology, 21(2), 123-132.

Cântar, I.C., Dincă, L. (2019). Agrostis species present in the "Alexandru Beldie" Herbarium from "Marin Dracea" National Institute for Research and Development in Forestry. Annals of the University of Craiova - Agriculture, Montanology, Cadastre Series, 48(2), 44-49.

Dincă, L., Peticilă, A. (2019). How many alder species (Alnus sp.) exist? A statistic based on herbarium vouchers. Scientific papers, Series B, Horticulture, 63(1), 613-619.

Dincă, L., Vasile, D., Dincă, M. (2017). Short characterisation of plant species from Centaurea genus present in Al. Beldie Herbarium from Marin Dracea National Institute for Research and Development in Forestry Bucharest. Annals of University of Craiova - Agriculture, Montanology, Cadastre Series, 47, 127-135.

Dincă, L., Dincă, M., Pantea, S.D., Timiş-Gânsac, V., Oneț, C. (2018). Amaranthus plant - between myth and usage. Natural Resources and Soustainable Development, 8(1), 9-16.

Enescu, R.E., Vechiu, E., Cantar, I. (2018). Herbarium survey of genus Gentiana L., Research Journal of Agricultural Science, 50(2), 51-59.

Mihai, B., Reynard, E., Werren, G., Savulescu, I., Sandric, I., Chitu, Z. (2009). Impacts of tourism on geomorphological processes in the Bucegi Mountains in Romania, Geographica Helvetica, 64, 134-147.

Sabudak, T., Guler, N. (2009). Trifolium L. - A review on its phytochemical and pharmacological profile. Phytotherapy Research, 23, 439 - 446.

Scărlătescu, V., Vasile, D., Dincă, L. (2017a). Plant species from "Al. Beldie" Herbarium-Orobanche genre-short description. ProEnvironment Promediu, 10(31), 191-198.

Scărlătescu, V., Vasile, D., Dincă, L. (2017b). The importance of Vaccinium species collection. Research Journal of Agricultural Science, 50(1), 194-201.

Tudor, C., Dincă, L. (2019). What can we learn about Bromus genus preserved in "Alexandru Beldie" herbarium? Research Journal of Agricultural Science, 51(4), 218-225.

Vasile, D., Dincă, L., Indreica, A., Voiculescu, I. (2016). Herbarul Alexandru Beldie - o colecție de plante şi o importantă bază de date pentru specialişti. Revista de Silvicultură şi Cinegetică, 39, 114-119.

Vechiu, E., Dincă, L., Bratu, I. (2018a). The characteristics of Polygonum plants present in the Alexandru Beldie Herbarium. Research Journal of Agricultural Science, 50(4), 378-384.

Vechiu, E., Dincă, L., Cântar, I.C. (2018b). Describing the Lycopodium Genus based on the plants present in Al. Beldie Herbarium. Research Journal of Agricultural Science, 50(4), 385-390. 


\section{Current Trends in Natural Sciences}

Vol. 9, Issue 17, pp. 160-167, 2020

https://doi.org/10.47068/ctns.2020.v9i17.019

Current Trends in Natural Sciences (on-line)

ISSN: 2284-953X

Current Trends in Natural Sciences (CD-Rom)

ISSN: 2284-9521

ISSN-L: 2284-9521

ISSN-L: 2284-9521

Zeljko, T., Petr, S., Nickolas, G., Andjeljko, P., Marijan, N., Andja, V. (2008). Hieracium-associated aphid parasitoid guilds (Hymenoptera: Braconidae: Aphidiinae) in Europe, Zootaxa, 1781, 20-30.

http://www.iucnredlist.org. IUCN 2019. The IUCN Red List of Threatened Species. Version 2019-1. Downloaded on february 2020.

http://www.theplantlist.org The Plant List (2013). Version 1.1. Published on the Internet; (accessed february 2020).

https://www.ipni.org (accessed february 2020).

https://ww2.bgbm.org/EuroPlusMed/query.asp (accessed july 2020). 